\title{
SPLETITÉ CESTY SOCIOLOGICKÉ IMAGINACE ANEB POUŤ ZA DOBRODRUŽSTVÍM IDEJÍ (EDITORIAL)
}

\author{
JAKUB MLYNÁŘ \\ Katedra sociologie Filozofické fakulty Univerzity Karlovy \\ E-mail: jakub.mlynar@ff.cuni.cz \\ MIROSLAV PAULÍČEK \\ Katedra zdravotně-sociálních studií Fakulty sociálních studií Ostravské univerzity \\ E-mail: miroslav.paulicek@osu.cz
}

\begin{abstract}
„Možná, že imaginace dospěla k místu, na němž se může opět ujmout svých práv.“

André Breton: Manifest surrealismu
\end{abstract}

Když v roce 1997 uspořádala Mezinárodní sociologická asociace (ISA) mezi svými členy anketu o nejvýznamnější sociologickou knihu 20. století, na druhém místě žebříčku se umístila Sociologická imaginace Charlese Wrighta Millse (1916-1962). Trvalý úspěch této dnes již klasické knihy s sebou přináší řadu nesnadných otázek: Do jaké míry dnes tuto knihu chápeme tak, jak její autor zamýšlel, že bychom ji chápat měli? A je to vůbec podstatné? Jak moc se proměnila společnost a sociologie a jak tyto proměny ovlivňují naši recepci knihy? A kdo tuto knihu ještě vůbec čte? Čteme ji celou, nebo ji spíš známe z učebnic? Nebo už socioložky a sociologové znají a v rozmanitých souvislostech používají jen její atraktivní název, bezesporu „dokonale zvolený a snadno zapamatovatelný“, „razantní a často napodobovaný“ (Balon, 2009, s. 1057)? ${ }^{1}$

Od vydání Sociologické imaginace uplynulo v roce 2019 již 60 let, což se stalo vhodnou př́ležitostí pro nejrůznější zamyšlení nad minulým, současným i budoucím životem této knihy. Proto je toto monotematické číslo AUC Philosophica et Historica Studia Sociologica věnováno ozvěnám, reflexím, retrospektivám a výhledům spojeným s Millsovou nejslavnější knihou, přičemž přímo navazujeme na kolokvium Šedesát let Sociologické imaginace, které dne 29. března 2019 společně uspořádala sekce sociologické teorie České sociologické společnosti a Katedra sociologie Filozofické fakulty Univerzity Karlovy. Sociologická imaginace byla v češtině publikována dvakrát: poprvé roku 1968 v nakladatelství Mladá fronta, podruhé pak roku 2002 (resp. 2008) v Socio-

\footnotetext{
1 Na tomto místě je vhodné poznamenat, že v oblasti historie a archeologie použil již v roce 1935 sousloví historická imaginace Robin George Collingwood, přičemž měl na mysli vrozené dispozice k myšlení, které umožňují studentům historie rekonstruovat minulost (srov. Little, 1983; Soffer, 1996); poté však i historická imaginace nabyla jiných, výrazněji sociologických významů (viz např. Skocpol, 1984). V psychologii se později objevila psychologická imaginace - v př́mé návaznosti na Millsovu knihu - jako schopnost vidět lidskou subjektivitu v sociálních a historických souvislostech (Staeuble, 1993).
} 
logickém nakladatelství (SLON). Podrobnosti o přípravách druhé verze překladu nabízí v tomto svazku Alena Miltová, která zároveň poskytuje vhled do neviditelných a leckdy nesnadných postupů nakladatelské praxe. Vycházeli jsme tedy z předpokladu dlouhodobého působení Millsovy knihy, která určitým způsobem ovlivnila několik generací českých i slovenských socioložek a sociologů. Hlavním cílem kolokvia bylo „prodiskutovat dnešní relevanci Millsova díla v širokých souvislostech“ a tento obecný záměr se odráží i v přítomném čísle. Editorského úvodního slova bychom zde rádi využili zvláště ke stručnému zasazení Sociologické imaginace do širších kontextů Millsova uvažování a také do rámce pozdějšího uvažování o Millsovi. Co vydání Millsovy knihy v roce 1959 předcházelo a co po něm následovalo?

$S$ výhodou zpětného pohledu dnes můžeme právě prizmatem Sociologické imaginace nahlédnout rané Millsovo dílo, jež vznikalo na přelomu 30. a 40. let 20. století (Mills, 1939; 1940a; 1940b). Mezi jeho hlavní inspirace v této době patřila sociologie vědění Karla Mannheima, americký pragmatismus (John Dewey, George Herbert Mead, Charles Sanders Peirce), Kenneth Burke, Florian Znaniecki, sociální psychologie a filosofie jazyka. Zřetelná je rovněž návaznost na dobový strukturní funkcionalismus (Talcott Parsons, Robert King Merton), ovšem s důrazem na přesvědčení, že teoretické myšlení v sociologii musí vždy sloužit především empirickému zkoumání.

Sociologie vědění má v sobě podle raného Millse snoubit historický a sociálně-psychologický pohled: jejím cílem má totiž být vysvětlení vztahu mezi myšlením a sociální strukturou. V rozvíjení tohoto argumentu se Mills soustředí na roli jazyka a utváření významů jako sociálního chování, ale také na povahu procesu reflexe z hlediska významů a jazyka. Význam není cosi přítomného „uvnitř jedince“ či „v lidské hlavě“, není nám dán apriorně, ale je výslednicí sociálního dění a interakce: „významy symbolů jsou definovány a redefinovány sociálně koordinovaným jednáním“ (Mills, 1939, s. 676). Mills tak rozvíjí téměř wittgensteinovské, v každém př́padě dosti progresivní pojetí významu. Stále však zachovává dualitu vnitřku a vnějšku, pojímající proces myšlení jako soukromý a v jádru individuální proces. Jazyk je pak Millsem chápán jako prostředek „Zveřejněni“ individuálních myšlenek, $\mathrm{z}$ čehož vyplývá problém vzájemného porozumění a neshody na významech (např. třídní konflikt), jež působí kolaps jednání a následnou postupnou proměnu těchto významů. „Perceptuální schéma“ podle Millse (1940a) podléhá mocenskému vlivu kulturní elity a jazyk je třeba chápat jako systém sociální kontroly. Již v rané tvorbě se tak odráží i Millsova citlivost vůči mocenské dynamice a zohlednění konfliktu jako významného zdroje sociální změny, což se později stalo jedním z ústředních témat jeho vrcholného díla, jak patrno i z obsahu př́íspěvků v tomto čísle.

Nejvlivnějším z Millsových raných textů je bezesporu článek o slovnících motivů situovaného jednání (Mills, 1940b). Jeho cílem je výklad „motivü“v kontextu sociologické teorie jazyka a sociální psychologie, tj. teorie vysvětlení (angl. accounts). Motivy nejsou psychické „síly“ působící skrytě uvnitř jedince, ale jsou to „slova ... odkazující k předpokládaným situačním důsledkům sporného jednání“ (Mills, 1940b, s. 905). Stabilní slovníky motivů jsou pak charakteristické pro určité části společnosti (jsou tedy sociálně strukturované), ale zároveň kulturně-historicky specifické: Mills si v USA své doby všímá např. klesajícího významu náboženských slovníků motivů a rostoucího významu tržních slovníků motivů. Podle Millse můžeme podobným zpo̊sobem analyzovat i teorie motivace vlivné v určité době (např. terminologie psychoanalýzy, marxismu, křest’anství) 
a odhalit, jak se „morálně“ zakotvené jazykové chování stává součástí sociální kontroly. Millsův program je zde zřetelně empirický, soustředěný na porozumění kontextualizovanému jednání. „Motivy jsou bez hodnoty,“ píše Mills, „pokud se nacházejí mimo vymezené sociální situace, pro něž jsou odpovídajícími slovníky. Musejí být situované“ (1940b, s. 913). Anne W. Rawls (2002, s. 3) klade Millsův raný článek o slovnících motivů do souvislosti s úsilím Ludwiga Wittgensteina a Harolda Garfinkela. Podle jejího soudu všichni tři myslitelé v podobné době nezávisle na sobě rozvinuli alternativní přístup k základním filosofickým otázkám vědění a významu, resp. sociálního řádu. Jejich přístup vychází ze „zdánlivých nahodilostí běžné sociální praxe, jež se ovšem při bližším zkoumání ukazuje jako důkladně uspořádaná.

Jak nedávno poznamenal Tomáš Kobes, již v raných Millsových textech se projevuje postup, kterým se vyznačuje i sama sociologická imaginace: „Subjekt je nahrazován sociální situovaností či sociální strukturou“ (2019, s. 155). V tomto ohledu lze nacházet podobnosti mezi ranými Millsovými texty a jeho nejslavnější knihou: „Život jednotlivce nelze správně pochopit bez jeho vztahu k institucím, v jejichž rámci žije. Tento život se skládá ze získávání, ztráty a modifikace rolí, a zejména z velmi niterného přecházení z jedné role do druhé,“ píše Mills (2002, s. 174). „Avšak pohled na člověka jako na sociální bytost nám umožňuje jít mnohem dál za jeho pouhou vnější biografii jako řadu sociálních rolí,“ pokračuje o několik odstavců dále. „Snad nejradikálnějším objevem soudobé psychologie a sociální vědy je objev, že četné nejniternější rysy osobnosti se řídí sociálními vzory, a jsou dokonce vštěpovány. (...) Motivace lidské činnosti, a dokonce i různý rozsah, v němž si je různé typy lidí typicky uvědomují, je třeba chápat v souvislosti se ,slovníky motivư převládajících ve společnosti a se sociálními změnami a nejasnostmi v nich“ (Mills, 2002, s. 175). I přes zřetelné odlišnosti akcentů tudíž můžeme v Millsově raném díle spatřovat předzvěsti řady témat, které $\mathrm{v}$ jiném kontextu či soustředěněji rozpracoval v Sociologické imaginaci. Již od prvních publikovaných textů pozorujeme některé charakteristické aspekty Millsova díla jako celku: (1) důraz na vzájemné působení sociálně-psychologických a historických prvků, které mají vliv na podoby sociálních uspořádání a institucí; (2) odpor k „neukotvenému teoretizování, tedy k teorii budované bez empirického ohledu (třebaže sám Mills empirický výzkum provozoval spíše nerad); (3) lidské jednání je vždy (historicky a společensky) situované, nelze proto uvažovat o transcendentní a univerzální „lidské podstatě“; (4) citlivost vưči sociálnímu konfliktu a mocenskému působení (téma elit). K poslednímu z uvedených bodů v tomto monotematickém čísle podrobněji přispívá stat Ondřeje Lánského.

Obratme se nyní k tomu, co po vydání Sociologické imaginace následovalo. Pozdější život této knihy můžeme sledovat v mnoha různých rovinách. Vzpomínkově laděný text Dilbar Alievy v přítomném svazku zasvěceně líčí, jak se s Millsovou knihou již záhy po vydání vyrovnávala sociologická obec na východ od železné opony. Zároveň Sociologická imaginace našla - a dodnes si drží - své pevné místo v kontextu anglosaské radikální sociologie, o čemž ostatně píše Miloslav Petrusek v doslovu k novému českému vydání (2002/2008). Tato rovina zůstává stále vysoce aktuální už tím, že neoddělitelně zahrnuje reflexi sociologie samotné. Mills se bezesporu stal inspirativním klasikem v oblasti hodnotící, kritické, veřejné a angažované sociologie, která by byla „relevantní ve vztahu ke společenské spravedlnosti“ (Mehan, 2008, s. 77) - tímto směrem kráčí i některé další příspěvky v tomto čísle AUC, zejména texty Miroslava Tížika a Jána Mišoviče. 
Největší proslulost ovšem Millsovi nepochybně zajistilo ono tajuplné sousloví „sociologická imaginace“. Začněme jeho rozkladem. Podstatné jméno v názvu Millsovy knihy zachycuje imaginaci či představivost - koneckonců, jak poznamenává v tomto čísle Tížik, i Millsův koncept se takto někdy do češtiny překládal. Jak bychom se tedy mohli pokusit porozumět imaginaci jako takové? Uzavírá nějak množinu jejích významů adjektivum „sociologická“? A v jakém vztahu je k významu, který dává tomuto slovu Mills ve své knize?

Psychologický pojem imaginace bývá definován jako lidská schopnost vyvolat v mysli obrazy něčeho, co není v danou chvíli př́imo zakoušeno smysly. Může se jednat o obrazy vázané $\mathrm{k}$ předchozí zkušenosti (tzv. reproduktivní imaginace) nebo obrazy vytvářející na základě dřívější zkušenosti něco nového (tzv. produktivní imaginace). Imaginace je tak schopností veskrze tvořivou (Boorstin, 1992), umožňující uspořádat známé prvky do nových a překvapivých konstelací. V tomto také spočívá význam imaginace v umění; ovšem extenze tohoto pojmu je mnohem širší. Český sociolog a historik Bedřich Baumann ve svém exilovém opus magnum s názvem Imaginative Participation velmi výstižně o sémantické bohatosti slova imaginace píše, že jde o „neproniknutelný a spletitý cíp země s rozmanitými obyvateli, kteří mluví různými nářečími a nosí různé oděvy,“ zahrnující „inspiraci, objasnění, vynalézavost, intuici, fantazii, kreativitu, introspekci, vědění a vkus“ (Baumann, 1975, s. 95).

Baumannova národopisná metafora nás navrací k vědám o společnosti. Jaký konkrétní význam slovo „imaginace“ získává u Millse? Je to význam pouze jediný? A lze tento význam smysluplně vztáhnout k současné podobě sociologického myšlení a bádání? At’ už je připisována obyčejným lidem, žurnalistům, umělcům nebo učencům, sociologická imaginace je „duševní schopnost, která by jim pomohla využít správně informací a rozvinout jejich rozum tak, aby získali jasný celkový obraz o tom, co se děje ve světě a k čemu může dojít v nich samých“ (Mills, 2002, s. 9). V tomto smyslu můžeme sociologickou imaginaci chápat jako určitou protiváhu vysvětlení založených na „zdravém rozumu“, ale i jako protiváhu př́liš redukcionistického nebo pramálo srozumitelného scientismu. Tímto napětím se do hloubky zabývá dosud nevydaný text Miloslava Petruska, který nám laskavě poskytla Alena Miltová a který jsme se rozhodli do tohoto čísla zařadit, přestože se Millsovu dílu explicitně nevěnuje.

Sociologická imaginace nespočívá ve vyvolávání mentálních obrazů nepřítomných objektů, ale spíše v zasazování známých objektů do nových vzájemných souvislostí. Millsova sociologická imaginace je představivostí povahy vztahů mezi celkem a jeho částmi, která lidem umožní pochopit, „co se děje ve světě“ a „co se odehrává v nich samých jako miniaturních společenských průsečících biografie a historie“ (Mills, 2002, s. 11). Toto klasické millsovské téma, v němž se odráží dualita individualismu a holismu, ve svém příspěvku k přítomnému číslu AUC rozvíjí Jiří Šubrt. Millsova „imaginace“ ovšem $\mathrm{z}$ tohoto pohledu není v pravém slova smyslu tvořivou schopností. Jde spíš o schopnost „pořádajíci“ či „interpretativní“ - jejím cílem je „adekvátni“ výklad světa, nazření společenské skutečnosti v její opravdové podstatě a zároveň odhalení našeho vlastního místa $\mathrm{v}$ tomto širším historickém a společenském rámci. Millsova sociologická imaginace je tak schopností proniknout k čemusi skrytému a zahlédnout dříve nespatřený a neviditelný řád světa. Podobni zajatcům osvobozeným z okovů v Platónově jeskyni, lidé jsou prostřednictvím sociologické imaginace „jakoby náhle probuzeni v domě, který se jim 
dosud jen zdál důvěrně známý“ (tamtéž, s. 12). Spíše než představování je předmětem sociologické imaginace proměna ve způsobu nahlížení a zároveň i způsobu zakoušení. Millsova sociologická imaginace je jistě způsobem vidění světa, nikoliv však světa neexistujícího a neprrítomného, ale právě světa bezprostředně reálného a veskrze skutečného. Na rozdíl od „imaginárna“, onoho představovaného, jež v imaginaci uchopujeme a které je jakousi „neskutečností“ (irreality) (Sartre, 2004, s. 125), se Millsova imaginace paradoxně soustředí na realitu. Předmětem millsovské imaginace je realita, která je v jistém smyslu skutečnější než skutečnost: realita zbavená závoje „falešného vědomí. Hlavním tématem Millsovy knihy je vlastně to, co se dnes většinou označuje jako „reflexivita“: nejen reflexivita sociologie jako historicky a společensky zakotvené snahy lidí porozumět povaze vlastního pospolitého života, ale také reflexivita samotných aktérů v jejich sociální situovanosti.

Všechny významy, které Mills (at’ už záměrně, či bezděčně) vložil do sousloví „sociologická imaginace“, se ukazují jako těžko uchovatelné ve chvíli, kdy je potřeba je př̀ložit do jiných jazyků. Většina překladů se drží původního substantiva imaginace, které však má i v jiných jazycích odlišné konotace. Dáme-li slovo surrealistům, pro něž je „imaginace“ pojmem naprosto klíčovým, pak například v německé verzi můžeme nalézt následující problém: „Pojem ,imaginace bývá překládán do němčiny slovem ,Einbildungskraft‘. Avšak toto slovo není jen nevinným překladem, ale zároveň i výkladem, interpretací imaginace jako zdroje subjektivních, nereálných představ, tedy něčeho, co si pouze namlouváme (einbilden) a co postrádá jakoukoli reálnou substanci. Tak je imaginace apriorně vykázána $\mathrm{z}$ dosahu reality a v dalším plánu z dosahu podrobnějšího zájmu." (Nápravník, 1990, s. 6) Vztah imaginace k realitě formuluje - jistěže způsobem uměleckým, nicméně v našich souvislostech velice relevantním - Milan Nápravník tak, že „imaginace stejně jako ruka má reálnou schopnost udržet ve volném prostoru otevřenou břitvu“ (tamtéž). ${ }^{2}$

Shrneme-li vše, co vyplývá z Millsova populárního termínu v podstatě bez ohledu na překlady a výklady, pak se sociologická imaginace především stala pro sociologii novou, jedinečnou věcnou náplní, která vědě, jež má o sobě ze své podstaty permanentní pochybnosti, dodává jistotu a sebevědomí ve vztahu k jiným vědám, nadto také práci sociologů povyšuje na tvưrčí činnost hraničící s uměním. V původním, Millsově smyslu se ovšem sociologická imaginace objevuje již téměř výhradně v základních učebnicových textech, jinak se dá říci, že se od původního významu do značné míry odpoutala. Objevují se texty, které operují se sociologickou imaginací bez jediného odkazu na Millse (např. v souvislosti s postkolonialismem Bhambra, 2007), ale také texty, jejichž autoři tvrdí, že Millsovo pojetí sociologické imaginace je potřeba přehodnotit a nově vymezit (Fuller, 2006; Pyyhtinen, 2016). ${ }^{3}$ Například Steve Fuller (2006) se pokouší vytvořit „novou sociologickou imaginaci“ (obohacenou zejména o biologické teorie) s tím, že Mills by jistě nerozuměl polovině termínů v rejstříku Fullerovy knihy, sdíleje s Mill-

2 Němečtí překladatelé ostatně s tímto problémem zápolí dodnes. První německé vydání Sociologické imaginace z roku 1963, následně dosti kritizované, neslo název Kritik der soziologischen Denkweise (přičemž byly zvažovány i názvy jako Die Illusion der Soziologie, př́ípadně nepř́liš atraktivní Soziologie und Gesellschaft či Gesellschaft und Geschichte [Römer, 2016, s. 336]). V roce 2016 bylo nahrazeno novým, byt podle některých kritiků opět zbytným vydáním s názvem Sociologická fantazie (Soziologische Phantasie).

3 Vztah imaginárna a sociálna rovněž ve 2. polovině 20. století získává na Millsovi patrně zcela nezávislé vyjádření v paradigmatu imaginaires (viz Alijevová, 2003). 
sem toliko „trochu paranoidní politickou senzibilitu, zjevné metodologické sympatie k pozitivismu, jeho alergii na módní akademický Newspeak (...) a jeho přesvědčení, že sociální věda je nezbytná, abychom mohli čelit (dnes velice odlišné) budoucnosti, která nás čeká“ (Fuller, 2006, s. vii). Finský sociolog Olli Pyyhtinen (2016) se zase snaží „obohatit a osvobodit“ Millsovo pojetí sociologické imaginace tak, aby nebylo nutné přepínat optiky pohledi̊ na jednotlivce a na struktury, ale abychom byli schopni vidět oboje zároveň. V tomto se opírá mimo jiné o uvažování Georga Simmela, Gillese Deleuze a zejména Bruna Latoura a dochází k perspektivě, kdy ve společnosti nevidíme jen lidské objekty, ale také aktéry ne-lidské (např. viry, geny, záplavy, počítače nebo odpadky) a vztahy mezi nimi.

Sociologická imaginace v pưvodním, Millsově významu je dnes oblíbená především v oblasti pedagogiky, a to jednak při výuce sociologie, jednak v souvislostech s učením kritickému myšlení, ovšem uvádí se, že v pedagogice lze využít sociologickou imaginaci ke zkvalitnění výuky v mnoha oblastech - od důrazu na srozumitelnost a zábavnost výkladu až po závažnější témata, jako jsou genderové nerovnosti nebo rasismus (Matthews, Edgington \& Channon, 2018). Naplňuje se tak Millsova idea, že sociologická imaginace je kompetence, kterou by si měli osvojit nejen sociologové. Koneckonců jedním z mála periodik, která v roce 2009 věnovala 50. výročí Sociologické imaginace zvláštní, monotematické číslo, byl časopis Teaching Sociology.

Neobyčejně zajímavé však je, že Millsova Sociologická imaginace dokáže stále vyvolávat rozdílná stanoviska, a to i v době, kdy do dějin sociologie patř́ jak Parsons s Lazarsfeldem, tak jejich zdrcující kritika, v době, kdy se - slovy Olli Pyyhtinena - „Z velké teorie a abstraktního empiricismu stal velký empiricismus a abstraktní teorie“ (2016, s. 3). Např́klad Jan Balon hodnotil v době druhého českého vydání knihy Millsovy pokyny a metodické imperativy v závěrečném Dodatku tak, že je nemohl „myslet úplně vážně“ (Balon, 2002), zatímco autor doslovu Todd Gitlin, který považuje Sociologickou imaginaci za „Millsovu nejtrvalejší knihu“, doporučuje číst tento dodatek všem postgraduálním studentům, protože v něm Mills upozorňuje, že sociologie je intelektuálním dobrodružstvím (Gitlin, 2002). Karel Hlaváček ve svém příspěvku k tomuto číslu AUC píše, že v současnosti musíme hledat nový př́běh, „ve kterém sociologická imaginace jakožto lidská schopnost dává smysl“. Jak už je v sociologii obvyklé, takových př́iběhů již celá řada existuje a další na svou šanci teprve čekají. Sociologická imaginace jako „dobrodružství idejí (Pyyhtinen, 2016, s. 2) proniká do př́iběhů vědeckých i každodenních, osobních i institucionálních; je na každém (nejen) sociologovi či socioložce, ve kterých budou smysl hledat a zda vůbec nějaký najdou. Alespoň několik námětů k tomuto hledání snad čtenáři naleznou i na následujících stránkách.

\section{LITERATURA}

Alijevová, D. (2003). Paradigma imaginárneho vo francúzskej sociálnej vede. In A. Kvasničková (Ed.), Paradigmy sociológie kultúry (s. 25-70). Univerzita Komenského v Bratislavě.

Balon, J. (2002). Jak se odstřelují posvátné krávy. Literární noviny 31 (2002).

Balon, J. (2009). Ambivalentní odkaz Millsovy Sociologické imaginace. Sociologický časopis / Czech Sociological Review, 45(5), 1055-1072.

Baumann, B. (1975). Imaginative Participation: The Career of an Organizing Concept in a Multidisciplinary Context. The Hague: Martinus Nijhoff. 
Bhambra, G. K. (2007). Rethinking Modernity. Postcolonialism and the Sociological Imagination. New York: Palgrave Macmillan.

Boorstin, D. (1992). The Creators: A History of Heroes of the Imagination. Toronto / New York: Random House.

Fuller, S. (2006). The New Sociological Imagination. London / Thousand Oaks / New Delhi: SAGE.

Gitlin, T. (2002). Doslov. In C. W. Mills, Sociologická imaginace (s. 247-261). Praha: Sociologické nakladatelství (SLON).

Kobes, T. (2019). O sociologické imaginaci. Sociální studia / Social Studies, 16(1), 147-162.

Little, V. (1983). What is Historical Imagination? Teaching History, (36), 27-32.

Matthews, C. R., Edgington, U., \& Channon, A. (Eds.) (2018). Teaching with Sociological Imagination in Higher and Further Education. Contexts, Pedagogies, Reflections. Singapore: Springer.

Mehan, H. (2008). Engaging the Sociological Imagination: My Journey into Design Research and Public Sociology. Anthropology \& Education Quarterly, 39(1), 77-91.

Mills, C. W. (1939). Language, Logic, and Culture. American Sociological Review, 4(5), 670-680.

Mills, C. W. (1940a). Methodological Consequences of the Sociology of Knowledge. American Journal of Sociology, 46(3), 316-330.

Mills, C. W. (1940b). Situated Actions and Vocabularies of Motive. American Sociological Review, 5(6), 904-913.

Mills, C. W. (2002). Sociologická imaginace. Praha: Sociologické nakladatelství (SLON).

Mills, C. W. (2016). Soziologische Phantasie. Cham: Springer.

Nápravník, M. (1990). Prostor tmy. Analogon 2, 4-12.

Pyyhtinen, O. (2016). More-than-Human Sociology: A New Sociological Imagination. New York: Palgrave Macmillan.

Rawls, A. W. (2002). Editor's Introduction. In H. Garfinkel, Ethnomethodology's Program: Working Out Durkheim's Aphorism (pp. 1-64). Lanham: Rowman \& Littlefield.

Römer, O. (2016). ,Kritik der soziologischen Denkweise': Zur deutschsprachigen Erstübersetzung der Sociological Imagination von 1963. In C. W. Mills, Soziologische Phantasie, p. 333-347.

Sartre, J. P. (2004). The Imaginary: A Phenomenological Psychology of the Imagination. London: Routledge.

Skocpol, T. (1984). Sociology's Historical Imagination. In T. Skocpol (ed.), Vision and Method in Historical Sociology (s. 1-21). Cambridge: Cambridge University Press.

Soffer, R. N. (1996). The Conservative Historical Imagination in the Twentieth Century. Albion: A Quarterly Journal Concerned with British Studies, 28(1), 1-17.

Staeuble, I. (1993). History and the Psychological Imagination. Annals of Theoretical Psychology, Vol. 8, 85-117. 